\title{
Tutkitun tiedon tuottajien ja tiedon käyttäjien palveluksessa
}

\author{
Ira Virtanen, Sanna Ala-Kortesmaa, \\ Sanna Herkama \& Tomi Laapotti
}

\begin{abstract}
Viittausohje:
Virtanen, I., Ala-Kortesmaa, S., Herkama, S., \& Laapotti, T. (2022). Tutkitun tiedon tuottajien ja tiedon käyttäjien palveluksessa. Prologi - Viestinnän ja vuorovaikutuksen tieteellinen aikakauslehti, 17(1), 4-7. https://doi.org/10.33352/prlg.113560

To cite this article:

Virtanen, I., Ala-Kortesmaa, S., Herkama, S., \& Laapotti, T. (2022). Tutkitun tiedon tuottajien ja tiedon käyttäjien palveluksessa [Being of service to the research-based knowledge providers and users]. Prologi - Journal of Communication and Social Interaction, 17(1), 4-7.

https://doi.org/10.33352/prlg.113560
\end{abstract}

Prologi

- Viestinnän ja vuorovaikutuksen tieteellinen aikakauslehti journal.fi/prologi/

ruotsiksi: Prologi - Tidskrift för Kommunikation och Social Interaktion englanniksi: Prologi - Journal of Communication and Social Interaction Julkaisija: Prologos ry.

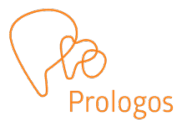

Avoin julkaisu / Open Access ISSN 2342-3684 / verkko ISSN 1795-7613 / painettu versio 


\section{Pääkirjoitus}

Prologi, 17(1)

4-7

https://doi.org/10.33352/prlg.113560

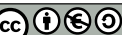

CC BY-NC-SA 4.0

\section{Tutkitun tiedon tuottajien ja tiedon käyttäjien palveluksessa}

Vuonna 2021 vietettiin Tutkitun tiedon teemavuotta. Teemavuosi oli opetus- ja kulttuuriministeriön, Suomen Akatemian ja Tieteellisten seurain valtuuskunnan (TSV) yhteinen hanke, joka toteutettiin laajan yhteistyöverkon kanssa. Teemavuoden tarkoituksena oli muun muassa tehdä entistä vahvemmin näkyväksi tutkimustietoa sekä tiedon luonnetta, johon kuuluu tiedon päivittäminen uusilla tutkimustuloksilla.

Prologin ja Tutkitun tiedon teemavuoden tavoitteet ovat samanlaiset. Prologos ry on julkaissut Prologi - Puheviestinnän vuosikirjaa vuodesta 2005 saakka. Tammikuussa 2021 Prologi muutettiin viestinnän ja vuorovaikutuksen tieteelliseksi aikakauslehdeksi. Aikakauslehti on vuosikirjaa notkeampi ja nopeampi palvelemaan tiedon tuottajia ja käyttäjiä sekä meidän tapauksessamme avoin ja ilmainen julkaisumuoto.
Prologin ollessa puheviestinnän vuosikirja, journaaliin pyydettiin artikkeliehdotuksia abstrakteilla kunkin vuoden alussa. Nyt lehden tavallisissa numeroissa tiiviistä ehdotuksista on siirrytty kokonaisten käsikirjoitusten vastaanottamiseen. Artikkeleita voi lähettää arvioitavaksi suomeksi, ruotsiksi ja englanniksi. Vertaisarvioitavat artikkelit, tutkimuspuheenvuorot, lectio praecursoriat ja kirja-arviot julkaistaan lehden verkkosivun Tulossa-välilehdellä heti, kun ne on taitettu. Tekstit kytketään numeroon sen ilmestyessä.

Aikakauslehdellä on omat verkkosivut TSV:n ylläpitämällä journal.fi-alustalla. Prologin verkkosivuja ylläpidetään kolmella kielellä ja ne täydentyvät jatkuvasti. Olemme tuottamassa sivuille muun muassa avointa tietoa vertaisarvioinnista sekä kattavat ohjeet vieraileville toimittajille teemanumeroiden toimittamisesta yhteistyössä Prologin toimituskunnan kanssa. 
Tieteellisen julkaisun tavoitteena on luonnollisesti edistää tutkitun tiedon saatavuutta ja yhteiskunnallista vaikuttavuutta. On tärkeää, että viestinnän ja vuorovaikutuksen tutkimuksella on lukijoita ja tutkitulla tiedolla käyttäjiä. Siksi kuuntelemme herkällä korvalla palautetta ja pyrimme kehittymään digitaalisessa tiedon saavutettavuudessa.

Keräsimme käyttäjäkokemuksia Prologos ry:n keväällä 2021 toteuttamalla jäsenkyselyllä sekä lokakuisessa Vuorovaikutuksen teemapäivässä. Kyselyvastaukset osoittavat, että avoin saatavuus ja suomenkielinen julkaiseminen ilahduttavat monia. Prologi tuntuu vakiinnuttaneen paikkansa viestinnän alan asiantuntijoiden keskuudessa. Vastausten perusteella monet hakeutuvat Prologin tekstien äärelle vahvistaakseen omaa asiantuntijuuttaan, päivittääkseen tietämystään ja pysyäkseen perillä tieteenalan kehityksestä. Tekstejä käytetään apuna opetuksessa ja ohjauksessa. Jatkossa Prologin toivottiin sisältävän johonkin teemaan keskittyviä numeroita ja esimerkiksi tekstejä, joissa tarkasteltaisiin viestinnän ja vuorovaikutuksen alan keskeisiä käsitteitä ja teorioita. Jos sinulla on käsikirjoitusidea tai aihio olemassa, toimituskunta tukee sinua mielellään sen kehittämisessä.

Vaikka painettua vuosikirja-Prologia on ollut mukava lukea, kyselyvastaukset osoittavat lukijoiden tukevan kestävää kehitystä ja lehden sähköistä julkaisemista. Prologos ry:n jäsenistö käsitteli paperisesta Prologista luopumista syyskokouksessaan Turussa 7.12.2021 ja päätti, että yhdistyksen julkaisutoiminta sitoutuu kestävän kehityksen periaatteisiin. Aikakauslehtimuotoisen Prologin ensimmäinen numero on siis myös viimeinen paperinen Prologi. Paperisessa vuosikirjassa on ennen tätä numeroa julkaistu 113 tekstiä, joista lähes 50 on vertaisarvioituja tutkimusartikkeleita. Lisäksi suurin osa Suomen puheviestinnän ja viestinnän alan väi- töskirjojen lectio praecursorioista on julkaistu Prologissa. Muistathan tarjota omaasi lehteen jatkossakin.

\section{Aikakauslehtihistorian ensimmäinen numero}

Prologi - Viestinnän ja vuorovaikutuksen tieteellisen aikakauslehden ensimmäisessä numerossa on vertaisarvioidun artikkelin lisäksi yksi keynote-puheenvuoro, neljä lectio praecursoriaa, yksi näkökulma-artikkeli sekä kaksi kirja-arviota. Prologin kustantaja Prologos ry osallistui virallisesti Tutkitun tiedon teemavuoteen Vuorovaikutuksen teemapäivä -tiedetapahtumalla. Teemapäivän aiheena oli "Etäisyys ja läheisyys" ja se järjestettiin Zoomissa 8.10.2021. Tapahtumassa jaettiin Vuoden vuorovaikutusteko -kunniamaininta sekä kolme gradupalkintoa, joista voit myös lukea lisää lehdestä.

\section{Tutkimusartikkeli ja puheenvuorot}

Vertaisarvioidussa artikkelissa Mari Puhakka, Mirja Tarnanen ja Emma Kostiainen selvittivät, millaisia merkityksiä opettajat ja rehtorit liittävät koulun yhtenäisen koulukulttuurin rakentamiseen ja miten opettajat ja rehtorit merkityksellistävät koulukulttuurin muutokseen sitoutumista. Tutkijat nimeävät yhdeksän diskurssia, joiden tuloksena he esittävät, että yhtenäiskoulun koulukulttuurin edistäminen hyötyisi jaetusta johtajuudesta. Jaettu johtajuus on pitkälti relationaalinen prosessi, joka edellyttää luottamuksesta viestimistä, vahvaa vuorovaikutusosaamista ja neuvottelua yhteisistä tavoitteista. Työyhteisössä tulisi voida käsitellä ristiriitaisiakin näkemyksiä ja odotuksia ja panostaa hyviin vuorovaikutuskäytänteisiin. 
Julkaistussa Vuorovaikutuksen teemapäivän keynote-puheenvuorossaan Ari Kuismin tarkastelee tilan ja ihmistoimijuuden välistä suhdetta sosiomateriaalisesta näkökulmasta. $\mathrm{Pu}$ heenvuoro keskittyy erityisesti organisaatioiden ja muuttuvan työelämän kontekstiin. Koska samat tilat voivat vaikuttaa ihmistoimijuuteen eri tavoin, on Kuisminin mukaan keskeistä osallistaa tilojen käyttäjät niiden suunnitteluun ja ylläpitämiseen. Lähes kaikki yhteiskunnan tilat voidaan nähdä mahdollisina tietotyön tiloina. Kuismin kannustaakin eri toimijoita avoimeen keskusteluun siitä, kenen ehdoilla tilajärjestelyjä toteutetaan ja tilan arkisia pelisääntöjä neuvotellaan, kun tavoitteena on edesauttaa kestävämmän työelämän rakentamista.

Kirsi-Marja Toivanen kertoo lektiossa väitöskirjastaan, jossa hän tutki nuoria kansainvälisen kaupan ammattilaisia. Tutkimuksessa Toivanen selvitti, miten relationaaliset työidentiteetit rakentuvat viestinnässä. Toivasen mukaan identiteettiä rakentavaa viestintää tapahtuu yhteiskunnan mikro-, meso- ja/tai makrotasoilla, mikä tekee myös diskursiivisesti rakentuvasta työidentiteetistä monikerroksisen ja dynaamisen. Ilmiön monipuolisen ymmärtämisen lisäksi hän on väitöskirjassaan tarkastellut identiteettityön, kieli- ja viestintäosaamisen ja koulutuksen kytköksiä opetussuunnitelmien kehittämiseksi.

Kati Timonen puolestaan tarkastelee lektiossaan vuorovaikutusosaamiseen kuuluvaa ryhmäosaamisen ilmiötä suomalaisessa lukiokontekstissa. Näkökulma aiheeseen on oppijakeskeinen: Timonen käsittelee opiskelu- ja työmaailmassa tärkeää taitoa nostamalla vahvasti lukiolaisten äänen ja käsitykset esiin. Hän osoittaa, että ryhmäosaamista on mahdollista kehittää, mutta vain jos siihen kiinnitetään riittävästi huomiota sekä oppimateriaaleissa että opetuksessa (ks. myös kirja-arvio äidinkielen oppikirjojen vuorovaikutusosioista tässä numerossa).

Anniina Kämäräinen käsittelee lektiossaan sitä, miten vuorovaikutuksen rakentumisen syvällinen ymmärtäminen auttaa tunnistamaan matematiikan oppimista edistäviä vuorovaikutustekijöitä. Väitöskirjatutkimuksessaan Kämäräinen keskittyi erityisesti oppituntien vuorovaikutuskäytänteiden tarkasteluun. Hänen mukaansa vertaisryhmässä tapahtuva ongelmanratkaisu edistää syvällistä oppimista - etenkin silloin, jos opiskelijoiden työskentelyä tarkkaileva opettaja osaa havaita ne hetket, jolloin tukea tarvitaan. Tällaisen oppimisen mahdollistaminen edellyttää kuitenkin toimintakulttuuria, jonka periaatteisiin sisältyy oppilaiden vuorovaikutuskeskeisten työskentelytaitojen tietoista ja tavoitteellista harjoittelua.

Jonna Koposen palvelujohtamisen alan väitöstutkimus kohdistui myynnin vuorovaikutusosaamiseen modernissa yritysten välisessä suhdemyynnissä. Koponen alleviivaa lektiossaan aiheen ajankohtaisuutta: teknologian kehitys on ollut nopeaa, myynnin muutos on vauhdittunut digitalisaation ja vallitsevan pandemian myötä, ja asiakaskäyttäytyminen ja vuorovaikutus on tiedostavaa ja monikanavaista. Tutkimus tunnisti neljä keskeistä myynnin vuorovaikutusosaamisen dimensiota, joiden avulla voidaan paremmin huomioida interpersonaalisen viestinnän taso esimerkiksi palvelujohtamisessa.

Englanninkielisessä näkökulma-artikkelissa Elina Melgin keskustelee julkisuusdiplomatiasta suomalaisessa viestintäkentässä ja suhdetoimintatyössä. Näkökulma tarjoaa katsauksen maakuvatyötä laajempaan osallistumiseen. Tekstissä kirjoittaja avaa uuden julkisuusdiplomatian käsitettä ja kannustaa alalla toimivia pohtimaan uuden julkisuusdiplomatian mahdollisuuksia omassa työssään. 


\section{Kirja-arviot ja tunnustukset}

Suvi-Tuuli Murumäki tarkastelee kirjaarviossaan kolmea äidinkielen ja kirjallisuuden oppikirjasarjaa, joissa on lukion uuden opetussuunnitelman mukaiset vuorovaikutukseen keskittyvät osiot. Nämä kirjasarjat ovat Ääni (Edita), Särmä (Otava) ja Loisto (Sanoma Pro). Arvio käsittelee kutakin kirjasarjaa vuorovaikutusosaamisen teoreettisen viitekehyksen ja kohderyhmän näkökulmista. Kirja-arvio muodostaa kattavan kuvan syksyllä 2021 voimaan tulleen opetussuunnitelman mukaisista vuorovaikutusosioista sekä esiteltyjen kirjasarjojen vahvuuksista.

Mitra Raappana perehtyi ja arvioi Saila Poutiaisen toimittaman teoksen Yleisö ja puhe - Kymmenen näkökulmaa esiintymiseen. Nimensä mukaisesti teos sisältää esiintymisen kysymyksiä muun muassa esitystutkimuksen, esityshistorian, fenomenologian, dialogismin, keskustelunanalyysin ja viestinnän etnografian näkökulmasta. Arviossaan Raappana antaa kiitosta kirjan tavanomaisesta esiintymiskirjallisuudesta poikkeavalle lähestymistavalle ja toteaa kirjan artikkelien tarjoavan lukijalleen paljon oivalluksia.

Vuonna 2021 Prologos jakoi kuudennen kerran vuoden Vuorovaikutusteko -palkinnon. Palkinto myönnettiin runsaasti Twitter-viestipalvelussa näkyvyyttä saaneen Twitter-kampanjan \#MinäTutkin käynnistäjille Tapio Määtälle ja Sami Syrjämäelle. Määtän ja Syrjämäen spontaani toiminta levisi laajalti Twitterissa ja on osoitus vuorovaikutuksen voimasta - moni tutkija innostui aihetunnisteen myötä kertomaan omasta tutkimuksestaan matalalla kynnyksellä. Keskustelu lisäsi tieteen näkyvyyttä ja edisti omalta osaltaan Tutkitun tiedon teemavuoden tavoitetta tehdä tutkimusta ja sen tekemistä näkyvämmäksi yhteiskunnassa.

Prologos ry jakoi kolmelle ansioituneelle pro gradu -työn tekijälle gradupalkinnon. Gradupalkinnon vastaanottivat Matilda Bogdanoff, Karoliina Karppinen ja Essi Salminen. Kaisa Laitinen ja Tomi Laapotti kirjoittavat kustakin työstä ja antavat palkittujen opinnäytetöiden tekijöille arvoisensa kiitokset. Tutkitulla tiedolla, pienellä ja suurella, on keskeinen merkitys tulevaisuuden rakentamisessa ja menneen ymmärtämisessä. Viestinnän ja vuorovaikutuksen kysymykset odottavat alati uteliaita ja eettisiä löytöretkeilijöitään.

Lämmin kiitos kaikille vuosikirjamuotoista, paperista Prologia toimittaneille, vuosikirjaan kirjoittaneille ja tekstejä arvioineille. Työnne tutkitun tiedon ja Prologin eteen on äärettömän arvokasta. Löydät kaikki Prologissa aiemmin julkaistut sekä uunituoreet tekstit Prologin verkkosivuilta (https://journal.fi/prologi). Tieteellinen aikakauslehti Prologi ottaa vastaan arvioitavia käsikirjoituksia ja muita tekstejä ympäri vuoden, ja tekstit ovat aina vapaasti luettavissa, ladattavissa ja jaettavissa. Toivomme, että aikakauslehtemme löytää jatkossa entistäkin laajemman lukijakunnan. Kerrothan hyödylliseksi kokemastasi sisällöstä eteenpäin!

Ira Virtanen, Sanna Ala-Kortesmaa, Sanna Herkama \& Tomi Laapotti

Prologin toimituskunta 2021-2022 